|Araştırma Makalesi / Research Article|

\title{
Otantik Liderlik Davranışlarının, Örgütsel Adalet ve Öğretmenlerin İ̧̧ Tatmini Üzerine Etkisinin Incelenmesi
}

\section{Investigation the Effects of Authentic Leadership Behaviors on Organizational Justice and Teachers' Job Satisfaction}

\section{Mehmet Yaşar Kılıç}

Anahtar Kelimeler
eğitim örgütleri
iş tatmini
otantik liderlik
otantik liderlik
davranışları
örgütsel adalet

\section{Keywords}

authentic leadership

authentic leadership

behaviors

educational

organizations

job satisfaction

organizational justice

Başvuru Tarihi/Received 25.12.2019

Kabul Tarihi /Accepted 07.10 .2020
Öz

Bu araştırmanın amacı; okul yöneticilerinin sergilediği otantik liderlik davranışlarının, örgütsel adalet ve öğretmenlerin iş tatmin üzerindeki etkisini belirlemektir. Bu etkiyi belirleyebilmek amacıyla bir model geliştirilmiş ve modelle ilgili hipotezler oluşturulmuştur. Bu araştırmanın evrenini 2018-2019 eğitim öğretim yılında Sivas il merkezinde görev yapan öğretmenler oluşturmaktadır. Araştırmanın örneklemini ise bu evrenden basit seçkisiz örnekleme yöntemi ile seçilen 261 öğretmen oluşturmaktadır. Çalışma "ilişkisel tarama" modeline uygun olarak yürütülmüştür. Çalışmada veri toplamak amacıyla "otantik liderlik ölçeği", "örgütsel adalet ölçeği" ve "iş tatmini ölçeği" kullanılmışır. Ölçek formunda, ölçeklerin doldurulması için gerekli talimatlara yer verilmiştir. Araştırmanın bulguları doğrultusunda elde edilen sonuçlara göre okul yöneticilerinin sergilediği otantik liderlik davranışlarının örgütsel adaleti pozitif yönde ve anlamlı olarak etkilediği sonucu ortaya çıkmıştır. Çalışmada elde edilen diğer bir bulgu ise okul yöneticilerinin sergilediği otantik liderlik davranışlarının iş tatminini pozitif yönde ve anlamlı olarak etkilediğidir. Ayrıca örgütsel adaletin iş tatminini pozitif yönde ve anlamlı olarak etkilediği sonucuna ulaşılmıştır. Araştırma sonucunda elde edilen bulgular başka çalışma bulguları ile karşılaştııılmış ve okul yöneticilerinin otantik liderlik davranışları konusunda gelişiminin sağlanabilmesi için teşvik edilmesi gerektiği önerilmiştir.

\section{Abstract}

The aim of this research is to determine the effect of authentic leadership behaviors of school administrators on organizational justice and teachers' job satisfaction. In order to determine these effects, a model was developed and hypotheses about the model were created. The population of this research is composed of teachers working in Sivas city center in 2018-2019 academic year. The sample of the study consists of 261 teachers selected by simple random sampling method. The study was conducted in accordance with the "relational survey" model. "Authentic leadership scale", "organizational justice scale" and "job satisfaction scale" were used in collecting data. The scale form provides instructions for filling the scales. According to the results of the study, it was found that authentic leadership behaviors exhibited by school administrators had a positive and significant effect on organizational justice. Another finding obtained from the study is that the authentic leadership behaviors exhibited by school principals have a positive and significant effect on job satisfaction. In addition, it has been concluded that organizational justice affects job satisfaction positively and significantly. The findings obtained as a result of the research were compared with other study findings and it was suggested that school administrators should be encouraged to improve their authentic leadership behavior. 


\section{Extended Abstract}

\section{Introduction}

Schools are an important part of the societies where education and training are directly implemented, students' development is ensured and various concrete applications are made (Lezotte, 1992). It is the strategic duty of schools to transfer the goals determined by countries to their interests (Kılıç, 2019). In this regard, societies that want to have a say in the future should take the necessary steps to increase the effectiveness of schools.

Creating an effective and efficient educational environment in schools is the responsibility of the school administrator (Reitzug, 1989). The effective and efficient use of human and material resources of the school is closely related to the leadership skills as well as the knowledge and skills of the manager (Akyüz, 2002). It is stated that the leadership characteristics of the school administrator are important for the efficiency of the school (Helvacı \& Aydoğan, 2011). In this respect, the concept of authentic leadership has gained importance in terms of exhibiting the desired behaviors of the school principal, which has an important role in order to meet the different environmental conditions and needs of the schools and increase the productivity (Keser \& Kocabaş, 2014). Today, leadership research focuses on authentic leadership, a process of leadership based on ethical behavior, as well as honesty, openness, transparency and respect for the changing demands of society (George, 2003; Walumbwa et al., 2008). In the studies, it is stated that authentic leadership behaviors are focused on honesty and ethical behaviors and create a perception of justice on employees (Kiersch \& Byrne, 2015). It is also stated that authentic leadership is associated with a large number of organizational outcomes (Walumbwa et al., 2008). It is stated that the perception of justice of the employees of the organization is an important factor in ensuring job satisfaction (DeConinck \& Stilwell, 2004). This study is important in terms of revealing the effect of authentic leadership behaviors of school principals on the organizational justice environment and teachers' job satisfaction. In addition, this study is thought to be useful in terms of providing resources and up-to-date information for similar studies on authentic leadership, organizational justice and job satisfaction in educational institutions in the future.

The aim of this research is to determine the effect of authentic leadership behaviors of school administrators on organizational justice and teachers' job satisfaction. In order to determine these relationships, a model was developed and hypotheses about the model were created. In order to determine these relationships, a model was developed and hypotheses about the model were created.

H1: Authentic leadership behaviors exhibited by school administrators affects organizational justice positively and significantly.

H2: The authentic leadership behaviors of the school administrators affects teachers' job satisfaction positively and significantly.

H3: Organizational justice affects teacher' job satisfactions positively and significantly.

\section{Method}

"Relational survey" model was used in the study. "Relational survey" is a research model aimed at revealing whether there is a co-change between two or more variables and the degree of change if there is a change (Karasar, 2013). Therefore, in this study, it is emphasized that the relationships between the authentic leadership behaviors, organizational justice and job satisfaction of the school administrators and the existence of the degree of existence. The population of this research is composed of teachers working in Sivas city center in 2018-2019 academic year. The sample of the study consists of 261 teachers selected by simple random sampling method. "Authentic leadership scale", "organizational justice scale"and "job satisfaction scale" were used in collecting data. The scale form provides instructions for filling the scales. The skewness and kurtosis coefficients of each subdimension were examined to check whether the data provided the univariate normality assumption. These coefficient values were between -1.5 and +1.5 . These results are indicative of the normal distribution of data (Tabachnick \& Fidell, 2013). Correlation coefficients between variables were examined to check whether multiple linear connection assumption was achieved. Büyüköztürk (2011) stated that the presence of a relationship between .80 and above between variables may lead to a multiple linear connection problem. When the correlation values were examined, there was no relationship that could lead to multiple linear connection problems.

\section{Result and Discussion}

According to the results of the study, it was found that authentic leadership behaviors exhibited by school administrators had a positive and significant effect on organizational justice. Another finding obtained from the study is that the authentic leadership behaviors exhibited by school principals have a positive and significant effect on job satisfaction. In addition, it has been concluded that organizational justice affects job satisfaction positively and significantly. Findings obtained from the research were compared with other research findings. 
Giriş

Eğitim ve öğretimin doğrudan uygulandığı, öğrencilerin gelişimlerinin sağlandığı ve çeşitli somut uygulamaların yapıldığı okullar toplumların önemli bir parçasıdır (Lezotte, 1992). Ülkelerin çıkarları doğrultusunda belirlediği hedeflerin öğrencilere aktarılabilmesi okulların stratejik görevidir (Kılıç, 2019). Bu bakımdan gelecekte söz sahibi olmak isteyen toplumlar, okulların etkililiğini artırabilmek için gerekli adımları atması gerekmektedir.

Okullarda etkili ve verimli eğitim-öğretim ortamının oluşturulması okul yöneticisinin sorumluluğundadır (Reitzug, 1989). Okulun sahip olduğu insan ve madde kaynaklarının faydalı bir şekilde kullanılması, yöneticinin sahip olduğu bilgi ve becerinin yanı sıra liderlik özellikleriyle de yakından ilişkilidir (Akyüz, 2002). Okul yöneticisinin liderlik özelliklerine sahip olmasının, okulun verimliliği açısından önemli olduğu ifade edilmektedir (Helvacı ve Aydoğan, 2011). Bu bakımdam okulların farklılaşan çevre koşullarına cevap verebilmesi ve uygulanan eğitimin verimliliğinin artırılabilmesi için okul müdürlerinin otantik liderlik özelliklerine sahip olması gerektiği üzerinde durulmaktadır (Keser ve Kocabaş, 2014). Günümüzde liderlik araştırmaları dürüstlüğü, açıklığı, şeffaflı̆̆ı, saygıyı içerisinde barındıran ve etik davranışlara dayanan bir liderlik süreci olan otantik liderliğe yoğunlaşmaktadır (George, 2003; Walumbwa ve diğerleri, 2008). Otantik liderlik davranışları dürüstlük ve etik davranışlar üzerine yoğunlaştığından, çalışanlar üzerinde adalet algısı oluşturduğu ifade edilmektedir (Kiersch ve Byrne, 2015). Ayrıca otantik liderliğin çok sayıda örgütsel çıktılarla ilişkisi olduğu bilinmektedir (Walumbwa ve diğerleri, 2008). Örgüt çalışanlarının adalet algılarının ise iş tatmini sağlamada önemli bir etken olduğu belirtilmektedir (DeConinck ve Stilwell, 2004). Bu bilgiler doğrultusunda bu çalışmada otantik liderlik davranışlarının örgütsel adalet ve iş tatmini üzerindeki etkisi incelenmiştir.

\section{Otantik Liderlik}

Otantik liderlik kavramı literatürde yeni bir kavram olmakla birlikte, modern liderlik teorileri arasında yerini almıştır (Chan, Hannah ve Gardner, 2005). Otantik liderlik, lider ve izleyenler arasında oluşabilecek pozitif yönlü ilişkiyi geliştirmeye yönelik karşılıklı olarak öz bilinç ve öz disiplin sağlama sürecinin oluşturulması ve sonuç olarak kişisel gelişimin sağlanmasını içeren bir liderlik sürecidir (Luthans ve Avolio, 2003). Avolio ve Gardner (2005) otantik liderliği, "karar vermek için gerekli olan bilginin paylaşılmasında açıklığı ilke edinen ve işgörenlerin görüş ve fikirlerini dikkate alan şeffaf bir yönetim anlayışı" olarak açıklamaktadır. Ilies, Morgeson ve Nahrgang, (2005)'a göre otantik liderler, sahip oldukları değerlerin ve inançların farkındadır. Bunun yanı sıra kendinden emin ve özgüvenli olarak hareket etmektedirler. Kendisini izleyenlerin güçlü yönlerini daha da geliştirme ve örgüt içerisinde çekici bir örgüt iklimi oluşturma üzerine odaklanmaktadırlar. Walumbwa ve diğerlerinin (2008) tanımlamalarında ise otantik lider, olumlu ahlaki kapasiteye sahip olan ve çevresini de bu yönde teşvik eden, benlik bilinci bulunan, içselleştirilmiş bir ahlaki bakış açısıyla hareket eden, bilgileri dengeli değerlendirebilen, ilişkilerde şeffaflığı benimseyen, takipçilerinin ve kendisinin sürekli gelişimi için çaba sarf eden bireyler olarak ifade edilmektedir. Caza ve diğerleri (2010)'ne göre otantik liderliğin temelinde bireyin kendisini tüm yönleriyle tanıması ve herhangi bir etkiye maruz kalmadan içinden geldiği gibi doğal davranışlar sergilemesi yatmaktadır. Literatür incelendiğinde otantik liderlik dört temel bileşen üzerinde yapılandırılmıştır. Bunlar; "özfarkındalık”, "bilgiyi dengeli değerlendirme”, "içselleştirilmiş ahlak anlayışı" ve "ilişkilerde şeffaflık" 'tır (Walumbwa ve diğerleri, 2008).

Özfarkındalık: Liderin kendi duygularını, düşüncelerini ve isteklerini gerçekçi bir şekilde değerlendirmesini ve bireysel özellikleriyle ilgili güçlü ve zayıf yönlerinin farkında olmasını ifade etmektedir (Kernis, 2003). Özfarkındalık becerisine sahip olan bir lider, kendisini çevresine açık bir şekilde ifade edebileceği gibi çevresindekilerin duygularını, düşüncelerini ve hislerini anlamlandırabilmektedir (Harvey, Martinko ve Gardner, 2006).

Bilgiyi Dengeli Değerlendirme: Elde edilen bilgiyi değiştirmeden, abartmadan doğrudan olduğu gibi ele alış biçimini ifade etmektedir (Kernis, 2003). Diğer bir ifadeyle, liderin karar verirken elinde bulundurduğu tüm bilgileri tarafsız olarak değerlendirmesi sürecidir (Walumbwa ve diğerleri, 2008). Bu bağlamda bir otantik lider, karar alırken ihtiyaç duyduğu bilgileri farklı kaynaklardan tarafsız olarak edinmeli ve tarafsız olarak değerlendirmelidir.

Içselleştirilmiş Ahlak Anlayışı: Otantik liderin ahlaki bir ikilemde kalmadan, sahip olduğu yüksek ahlaki standartlara göre hareket etmesidir (May ve diğerleri, 2003). Otantik liderin seçimlerinin, gereksinimlerinin ve sahip olduğu değerler bütününün davranışları ile uyum içerisinde olması gerekmektedir (Kernis, 2003).

iliş̧ilerde Şeffafık: Otantik liderler ilişkilerinde yüksek düzeyde açık olan, çevresi ile ilişki kurmada istekli davranışlar sergileyen ve ilişkilerinde güven duyulan bireylerdir (Gardner ve diğerleri, 2005). Bireyin açık bir şekilde kendisini ifade etmesi, çevresiyle iletişim halinde olması ve düşüncelerini takipçileriyle dürüstçe paylaşması ilişkisel şeffaflığın bir parçasıdır (Ilies, Morgeson ve Nahrgang, 2005).

\section{Örgütsel Adalet}

Örgütsel adalet, örgüt içerisinde adil ve ahlaki kurallara uygun olarak davranılmasını içermektedir. Örgütsel adalet iklimine sahip bir örgütte, çalışanlar yöneticilerinin davranışlarını adil ve ahlaklı olarak nitelendirirler (Pfeffer ve Langton, 1993). Örgütsel adalet örgüt içerisindeki kazanımların uygun dağıtılması, dağıtım kararlarının alınmasında etkili olan normlar ve kişiler arası uygulamalarda gerekli olan kurallar ile ilgilidir (Folger ve Cronpanzano, 1998). Greenberg (1996) örgütsel adaleti, çalışanın örgüt içerisindeki uygulamalarla ilgili adalet algısı olarak açıklamaktadır. Literatür incelendiğinde örgütsel adaletin üç temel kavram üzerinden incelendiği görülmektedir. 
Dağıtımsal Adalet: Örgüt içerisindeki kaynakların belirli standartlara ve kurallara uyularak adil bir şekilde dağıtılmasıdır (Cohen, 1987). Yavuz (2012)'a göre dağıtımsal adalet “örgütlerde ortaya çıkan kazanımların adil paylaşımını, ödül, ceza ve kaynakların örgüt üyeleri arasında adil dağılımı ile ilgili örgüt üyelerinin algılamalarını kapsayan bir adalet algısıdır". Dağıtımsal adalet, Adams'ın (1965) eşitlik teorisi temeline dayandırılmaktadır. Adams (1965)'a göre çalışan, örgüte kendisinin yaptığı katkılar neticesinde elde ettiği örgütsel çıktılar ile başka çalışanların sağladığı katkıları ve örgütsel çıktıları karşılaştırmaktadır. Bu karşılaştırma neticesinde çalışanlar örgütte adaletin varlığı hakkında karar verir. Moorman (1991), yöneticilerin adil davranması durumunda çalışanların yöneticilerine, işlerine ve örgüt çıktılarına karşı olumlu davranış biçimi sergilediğini ifade etmektedir.

Iş̧lemsel Adalet: Örgüt içerisinde karar alma sürecinde adil davranmak işlemsel adaletin gereğidir. Çalışanlar örgütte karar alma süreçlerine aktif olarak katılmak ve söz sahibi olmak isterler. Çalışanların bu sürece dâhil olması, örgütü adaletli olarak algılamaları için önemli bir etkendir (Folger ve Konovsky, 1989; Lind ve Tyler, 1988). Kim ve Mauborgne (1993), yöneticilerin adil ve katılımcı bir planlama sürecini uygulamaya koyması durumunda, çalışanların bu planı desteklediklerini, liderlerine daha fazla güvendiklerini ve onlara bağlılıklarının arttığını ifade etmektedir. Bunu destekler bir şekilde Kim ve Mauborgne (2005) işlemsel adalet olmadı̆̆ı zaman "entelektüel ve duygusal öfke" oluştuğunu ve bunun da "güvensizlik ve öfke" ile sonuçlandığını belirtmiştir.

Etkileşimsel Adalet: Yöneticilerin çalışanlara karşı olumlu davranışlar sergilemesi ve onlara alınan kararların ve işleyen süreçlerin gerekçelerini açıklaması etkileşimsel adaletin bir gereğidir (Colquitt, 2001). Benzer bir şekilde Bies ve Moag (1986) etkileşimsel adaleti, örgüt içerisinde gerekli prosedürler uygulanırken yöneticilerin çalışanlara dürüst davranması, onlara saygı duymaları ve onları bilgilendirmeleri olarak açıklamaktadır.

\section{İş Tatmini}

İş tatmini, çalışanların yaptığı işe karşı gösterdiği olumlu duygusal tepkiler olarak tanımlanabilir (Baş ve Ardıç, 2002). Locke (1976) iş tatminini, çalışanın yaptığı iş ve iş yerindeki deneyimlerinin sonucunda hissettiği olumlu duygu durumu olarak açıklamaktadır. Ugboro ve Obeng (2000) ise iş tatminini, bireyin çalışma hayatı ve çalıştığı iş yeri koşulları arasındaki uyum düzeyinin bir sonucu olarak, ortaya çıkan hoşnut olma hissi ve aynı zamanda bireyin yaptığı işe karşı takındığı pozitif tutum olarak açıklamaktadır.

Bireyin yaptığı iş, ekonomik açıdan önemli olduğu gibi sosyal ve psikolojik hayatında da önemli yere sahiptir. Çalışanın iş yerinde huzurlu ve mutlu olması bu açıdan önemlidir (Bakan ve Büyükbeşe, 2004). Benzer bir şekilde Barlı (2008), çalışanların yaşamlarının büyük bir çoğunluğunu iş yerlerinde geçirdiklerini, bu sebeple iş tatmininin rahat ve huzurlu bir yaşam için gerekli olduğunu vurgulamaktadır. Ayrıca iş tatmininin olmadığı örgütlerde, çalışanların yaptıkları eylemler neticesinde dolaylı ya da dolaysız olarak örgüte zarar verebileceği üzerinde durmuştur. Benzer bir şekilde Budak (2006) ise bireyin çalıştığı işten tatmin olmaması durumunda işe gitmede isteksizlik, verimliliğin azalması, hataların artması, işten uzaklaşma duygusu, kararsızlık, yüksek işgücü devri, disiplinsizlik, problemlere karşı duyarsızlaşma vb. problemlerin yaşanabileceğini ifade etmektedir. Özcan (2011) çalışanların yaptıkları iş ve iş yerinin sahip olduğu değerler arasında uyum olduğu zaman, amaçların gerçekleştirilebilmesinin ve iş tatmininin sağlanmasının yüksek düzeyde olabileceğini belirtmiştir. Ancak uyumsuzluk yaşandığı durumda iş tatmininin azalacağını ve amaçların gerçekleşmesinde problemler yaşanacağını ifade etmiştir.

Literatür incelendiğinde iş tatmini üzerinde etkisi olan birçok etken bulunmaktadır. Bu etkenler bireysel ve örgütsel faktörler olarak ele alınmaktadır. Özaydın ve Özdemir (2014) bireysel faktörleri yaş, kıdem, cinsiyet, eğitim seviyesi, kişilik özellikleri, temel yetenek düzeyi, inançları ve değerleri gibi özelliklerin oluşturduğunu ifade etmiştir. Luthans (1995) ise örgütsel faktörleri işin yükselme olanağı, işin kendisi, yönetim, ücret ve iş arkadaşları olarak sınıflandırmıştır.

\section{Otantik Liderlik, Örgütsel Adalet ve İş Tatmini Arasındaki iliş̧iler}

Literatür incelendiğinde otantik liderlik ile örgütsel adalet kavramının ilişkilendirildiği çok az çalışma olduğu ve bu çalışmaların da büyük bir kısmının yabancı çalışmalar olduğu görülmektedir. Kiersch (2012) tarafından yapılan çalışmada otantik liderlik ile örgütsel adalet arasında pozitif ilişkiler olduğu belirtilmiş, ayrıca örgütsel adaletin otantik liderlik ile çalışanların refahı, şirketten ayrılma niyetleri ve örgütsel bağlılık arasında arabuluculuk rolü oynadığı ifade edilmiştir. García-Guiu, Molero ve Moriano (2015) otantik liderlik, grup uyumu, örgütsel kimlik ve örgütsel adaletin potansiyel etkisi arasındaki ilişkiyi ortaya çıkarmak için yaptıkları araştırmada, otantik liderlik ile örgütsel adalet arasında pozitif yönde ilişkiler olduğu belirtilmiştir. Shamir ve Eilam (2005) otantik liderlerin sahip oldukları değer yargılarında adaletli davranmanın önemli bir yer tuttuğunu ifade emektedir. Otantik liderler ancak çalışanlara adaletli davranmasıyla kendisine karşı güven duygusunun oluşabileceğini ve oluşan güvenin sürdürülebileceğini bilmesi gerekmektedir. Liderler için güvenin çok önemli bir etken olduğu göz önünde bulundurulursa, örgütte adaletli bir iklimin yaratılması lider için hayati bir durum olduğu söylenebilir.

Otantik liderlik ile iş tatmini kavramlarının ilişkilendirildiği çalışmalara bakıldığında ulusal literatürde oldukça az çalışma yapıldığı görülmektedir. Bu çalışmalardan birisinde Ayça (2016) otantik liderliğin iş tatminini büyük ölçüde açıkladığını belirtmiştir. Farklı bir çalışmada ise Pür (2019), otantik liderliğin iş tatminini pozitif yönde etkilediği sonucuna ulaşmıştır. Uluslararası literatür incelendiğinde ise Darvish ve Rezaei (2011) otantik liderliğin iş tatmini üzerindeki etkilerini ortaya çıkarmak amacıyla yaptığı araştırmada, otantik liderlik ile iş tatmini arasında olumlu ilişkiler olduğunu belirtmiştir. Choi ve Ahn (2016) ise otantik liderliğin iş tatmini üzerinde önemli etkilerinin olduğunu ifade etmiş ve iş tatmininin sağlanabilmesi için yöneticilerin otantik liderlik özelliklerini geliştirmesi gerektiği üzerinde durmuştur. 
Örgütsel adalet ve iş tatmini kavramlarının da literatürde birbiri ile ilişkili kavramlar olarak kullanıldığı görülmektedir. Tanrıverdi ve Paşaoğlu (2014) okullar evreninde yaptığı çalışmada, örgütsel adaletin öğretmenlerin iş tatmin düzeylerini olumlu olarak etkilediğini ifade etmiştir. Farklı bir çalışmada ise Altınkurt ve Yılmaz (2012), örgütsel adaletin iş doyumunu yordadığını bulgulamıştır. Zainalipour, Fini ve Mirkamali (2010) ise yaptıkları çalışmada okullardaki örgütsel adalet ve iş tatmini arasında pozitif yönlü ilişkilerin bulunduğu sonucuna varmıştır. Elma (2013), prosedürel ve etkileşimsel adaletin, öğretmenlerin iş doyumları üzerinde önemli bir yordayıcı değere sahip olduğunu belirtmiştir. Yapılan birçok çalışmada örgütsel adalet ve iş tatmini birbiriyle ilişkili kavramlar olarak ele alınmıştır (Altahayneh, Khasawneh ve Abedalhafiz, 2014; Chen McCain, Tsai ve Bellino, 2010; Demir, 2016; Karimi ve diğerleri, 2013; Malik ve Naeem, 2011; Nojani ve diğerleri, 2012; Sia ve Tan, 2016).

Bu çalışma, okul müdürlerinin sergiledikleri otantik liderlik davranışlarının, örgütteki adalet ortamına ve öğretmenlerin iş tatminine sağladıkları etkiyi ortaya koyması açısından önemlidir. Okul müdürlerinin sahip olduğu liderlik özelliklerinin okulda adalet ortamının oluşması ve iş tatminin sağlanması açısından belirleyici etken olduğu söylenebilir. Okul müdürünün özfarkındalığı, bilgiyi dengeli olarak değerlendirebilme becerisi, ahlak anlayışı ve ilişkilerindeki şeffaflık davranışının bir bütün olarak okuldaki etkilerinin pozitif yönde olabileceği düşünülmektedir. Özellikle okul müdürünün olumlu bir ahlak anlayışına sahip olması pozitif okul ikliminin oluşmasına, dolayısıyla örgütsel adaletin gelişimine yardımcı olabilir. Örgütsel adaletin öğretmenler üzerindeki etkileri dikkate alındığında, örgütsel adalet oluşumunun sağlanmasında etkili olan unsurların araştırılmasının önemli olduğu düşünülmektedir. Ayrıca otantik liderlik literatürü göz önünde bulundurulduğunda iş tatminini doğrudan, örgütsel adalet üzerinden ise iş tatminini dolaylı olarak etkileyebileceği üzerinde durulmaktadır. Okullarda etkili ve verimli bir eğitim-öğretim ortamının oluşturabilmesi ve öğretmen performansının artırılabilmesi için iş tatmininin sağlanabilmesi önemli bir etkendir (Arifin, 2015; Büyükgöze ve Özdemir, 2017; Chamundeswari, 2013; Yazıcıoğlu, 2010). Bu açıdan bakıldığında otantik liderliğin örgütsel adalet ve iş tatmini üzerindeki olası etkilerinin araştırılması var olan durumun ortaya çıkarılmasını sağlayacaktır. Öğretmenlerin iş tatmininin sağlanmasında bu değişkenlerin etkilerinin belirlenmesinin, okulun amaçlarına ulaşabilmesi açısından gerekli bir durum olduğu düşünülmektedir. Bunun yanı sıra bu çalışmanın gelecekte eğitim kurumlarında otantik liderlik, örgütsel adalet ve iş tatmini ile ilgili yapılacak benzer çalışmalara kaynak ve güncel bilgi sağlaması açısından faydalı olabileceği düşünülmektedir.

\section{Araştırmanın Amacı}

Bu araştırmanın amacı; okul yöneticilerinin sergilediği otantik liderlik davranışlarının, örgütsel adalet ve öğretmenlerin iş tatmini üzerindeki etkisini belirlemektir. Bu etkiyi belirleyebilmek amacıyla bir model geliştirilmiş ve modelle ilgili hipotezler oluşturulmuştur. Oluşturulan hipotezler aşağıdaki gibidir.

H1: Okul yöneticilerinin sergiledikleri otantik liderlik davranışları, örgütsel adaleti pozitif yönde ve anlamlı olarak etkilemektedir.

H2: Okul yöneticilerinin sergiledikleri otantik liderlik davranışları, öğretmenlerin iş tatminini pozitif yönde ve anlamlı olarak etkilemektedir

H3: Örgütsel adalet, öğretmenlerin iş tatminini pozitif yönde ve anlamlı olarak etkilemektedir

Oluşturulan modele ilişkin yol diyagramı aşağıda verilmektedir.

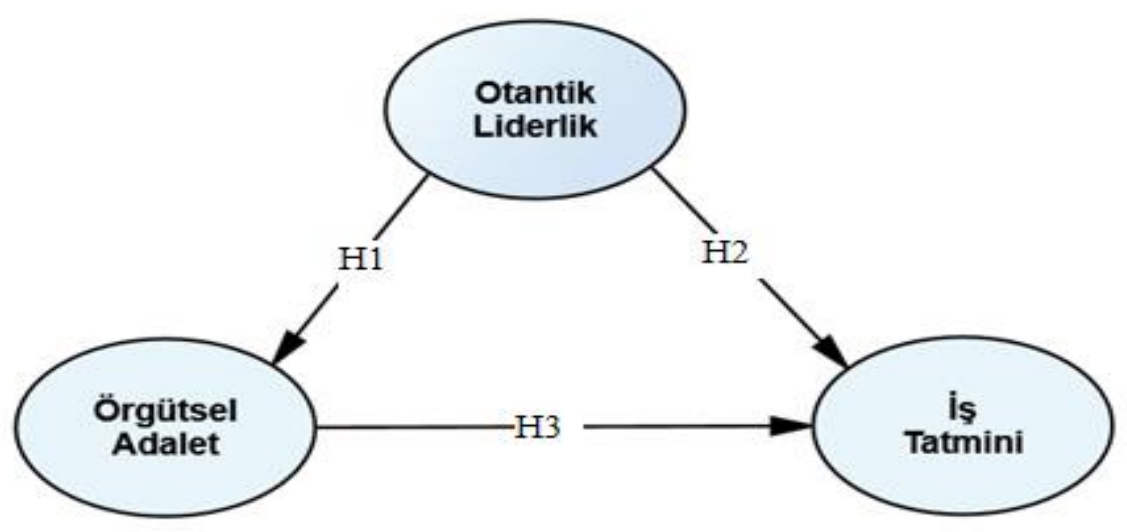

Şekil 1. Oluşturulan model ve yol diyagramı

\section{YÖNTEM}

Bu araştırmada okul yöneticilerinin sergilediği otantik liderlik davranışlarının, örgütsel adalet ve öğretmenlerin iş tatmini üzerindeki etkisi belirlenmeye çalışılmıştır. Bu doğrultuda çalışmada "ilişkisel tarama" modeli kullanılmıştır. "iliş̧isel tarama", birden fazla değişken arasındaki değişimin varlığını, eğer değişim varsa bu değişimin derecesini ortaya çıkarmayı amaçlayan araştırma modelidir (Karasar, 2013). Dolayısıyla bu çalışmada okul yöneticilerinin sergilediği otantik liderlik davranışlarının, 
örgütsel adalet ve öğretmenlerin iş tatmini etkileyip etkilemediği ve eğer etkiliyorsa bu etkinin derecesinin ortaya çıkarılması üzerinde durulmaktadır.

\section{Çalışma Grubu}

Bu araştırmanın evrenini 2018-2019 eğitim öğretim yılında Sivas il merkezinde görev yapan öğretmenler oluşturmaktadır Araştırmanın örneklemini ise bu evrenden basit seçkisiz örnekleme yöntemi ile seçilen 261 öğretmen oluşturmaktadır. Örneklemi oluşturan öğretmenlerin cinsiyet, eğitim durumu ve toplam öğretmenlik tecrübesine ilişkin bilgiler şu şekildedir: Öğretmenlerin $\% 41,4^{\prime}$ ü kadın ( $\left.f=108\right)$ ve $\% 58,6^{\prime}$ sı erkek ( $\left.f=153\right)^{\prime}$ dir. Ayrıca öğretmenlerin \%75,9'u lisans ( $\left.f=198\right)$ ve $\% 24,1^{\prime} i$ ise lisansüstü $(f=63)$ okul mezunudur. Son olarak öğretmenlerin \%19,5'i 1-5 yıl ( $f=51), \% 21,8^{\prime}$ i 6-10 yıl ( $\left.f=57\right), \% 25,3^{\prime} \ddot{u} 11-15$ yıl ( $\left.f=66\right), \% 19,9^{\prime} u$ 16-20 yıl ( $f=52)$ ve $\% 13,5^{\prime}$ i 21 yıl üzeri $(f=35)$ tecrübeye sahiptir.

\section{Veri Toplama Araçları}

Çalışmada veriler, "otantik liderlik ölçeği", "örgütsel adalet ölçeği”, ve "iş tatmin ölçeği” ile toplanmıştır. Ayrıca katılımcılara ait bazı demografik bilgilerin elde edilebilmesi için ölçek formunda bazı kişisel sorular yer almaktadır.

Otantik Liderlik Ölçeği: Ölçek orijinalinde Walumbwa ve diğerleri (2008) tarafından geliştirilmiştir. Ölçeğin Türkçe'ye uyarlanması Tabak, Polat, Coşar ve Türköz (2012) tarafından gerçekleştirilmiştir. Orijinalinde dört alt boyuttan ve 16 maddeden oluşmaktadır. Bu alt boyutlar "içselleştirilmiş ahlak anlayışı", "ilişkilerde şeffaflık", "bilgiyi dengeli değerlendirme” ve "özfarkındalık” olarak isimlendirilmiştir. Türkçe'ye uyarlama çalışmasında ölçeğin dört faktörlü yapısı doğrulayıcı faktör analizi (DFA) sonucunda teyit edilmiştir. Ölçek 5'li Likert olarak (1-Hiçbir zaman, 5-Her zaman) hazırlanmıştır. Ayrıca ölçeğin Türkçe'ye uyarlama aşamasında güvenirlik analizi yapılmış ve Cronbach's Alfa değeri "içselleştirilmiş ahlak" boyutu için .83, "ilişkilerde şeffaflık" boyutu için .86, "bilgiyi dengeli değerlendirme" boyutu için .85, "özfarkındalık" boyutu için .90 ve tüm ölçek için ise .93 olarak hesaplanmıştır. Bu çalışma verileriyle yapılan doğrulayıcı faktör analizi sonucunda uyum iyiliği değerleri X²/sd: $2.56 \mathrm{GFI}$ : 97 ; CFI: .96; AGFI: .93; NFI: .91; RMSEA: .04 ve SRMR: .02 olarak bulunmuştur. Bu değerlere göre ölçeğin uyum iyiliğinin iyi düzeyde olduğu ifade edilebilir (Baumgartner ve Homburg, 1996; Bayram, 2013; Kline, 2016). Bu çalışmada ölçeğin güvenirlik düzeyini belirleyebilmek amacıyla Cronbach's Alpha değerleri hesaplanmıştır. Bu değerler "içselleştirilmiş ahlak" boyutu için .85, "ilişkilerde şeffaflık" boyutu için .87, "bilgiyi dengeli değerlendirme" boyutu için .85, "özfarkındalık" boyutu için .86 ve tüm ölçek için ise .89 olarak hesaplanmıştır.

Örgütsel Adalet Ölçeği: Ölçek, Niehoff ve Moorman (1993) tarafından geliştirilmiş ve Türkçe'ye uyarlaması Polat (2007) tarafından yapılmıştır. Türkçe'ye uyarlanan ölçek 19 maddeden oluşmakta ve 3 alt boyutu bulunmaktadır. Bu alt boyutlar "dağıtımsal adalet", işlemsel adalet" ve "etkileşimsel adalet" olarak isimlendirilmiştir. Polat (2007) ölçeğe yaptığı açımlayıcı faktör analizi sonucunda, ölçeğin 3 faktörlü yapısının korunduğunu ve ölçekten madde atılmadığını ifade etmiştir. Yapılan güvenirlik analizi sonucunda ise ölçeğin Coronbach's Alpha değerleri "dağıtımsal adalet" boyutu için .89, "işlemsel adalet" boyutu için .95, "etkileşimsel adalet" boyutu için .90 ve tüm ölçek için .96 olarak hesaplanmıştır. Bu çalışma kapsamında ise yapılan doğrulaycı faktör analizi sonucunda uyum iyiliği değerleri X²/sd: 2.07 GFI: .95; CFI: .95; AGFI: .92; NFI: .90; RMSEA: .05 ve SRMR: .04 olarak hesaplanmıştır. Bu sonuçlara göre ölçeğin uyum iyiliği değerlerinin iyi düzeyde olduğu söylenebilir (Baumgartner ve Homburg, 1996; Bayram, 2013; Kline, 2016). Bu çalışma kapsamında yapılan güvenirlik analizinde Cronbach's Alpha değeri "dağıtımsal adalet" boyutu için .82, "işlemsel adalet" boyutu için .86, "etkileşimsel adalet" boyutu için .83 ve tüm ölçek için .88 olarak hesaplanmıştır.

Işs Tatmin Ölçeği: Öğretmenlerin tatmin düzeylerinin belirlenebilmesi amacıyla Weiss, Davis, England ve Lofquist (1967) tarafından oluşturulan "Minesota İş Tatmin Ölçeğinin” kısa formu kullanılmıştır. Baycan (1985) tarafından Türkçe'ye uyarlanan ölçek 20 madde ve 2 alt boyuttan oluşmaktadır. Bu alt boyutlar "içsel doyum" ve "dışşal doyum" olarak isimlendirilmiştir. "içsel doyum" 12 maddeden "dışşal doyum" ise 8 maddeden oluşmaktadır. Bu çalışmada ise ölçeği doğrulayabilmek için "doğrulayıcı faktör analizi" yapılmıştır. Analiz sonucunda uyum iyiliği değerleri X²/sd: 1.72 GFI: .98; CFI: .97; AGFI: .95; NFI: .93; RMSEA: .02 ve SRMR: .04 olarak bulunmuştur. Bu sonuçlar ölçeğin uyum iyiliği değerlerinin iyi düzeyde olduğunun göstergesidir (Baumgartner ve Homburg, 1996; Bayram, 2013; Kline, 2016). Yine bu çalışma kapsamında yapılan güvenirlik analizinde Cronbach's Alpha değeri "içsel doyum" boyutu için .80, "dışşal doyum" boyutu için .77 ve tüm ölçek için .84 olarak hesaplanmıştır.

\section{Verilerin Analizi}

Toplanan verilerin analizinde SPSS 21 "Statistical Packages for the Social Sciences" ve AMOS 24 "Analysis of Moment Structures 24" istatistik programından faydalanılmıştır. Veriler SPSS 21 programına girilerek eksik veri kontrolü yapılmış ve verilerin normallik testlerine bakıımıştır. Ayrıca katılımcıların demografik özelliklerine bakılarak yüzdeleri hesaplanmıştır. Verilerin tek değişkenli normallik varsayımını sağlayıp sağlamadığını belirleyebilmek amacıyla bütün alt boyutların çarpıklık ve basıklık katsayıları incelenmiştir. Bu katsayı değerlerinin -1.5 ve +1.5 arasında olduğu görülmüştür. Bu sonuçlar verilerin normal dağıldığının bir göstergesidir (Tabachnick ve Fidell, 2013). Çoklu doğrusal bağlantı varsayımının sağlanıp sağlanmadığını kontrol etmek için ise değişkenler arasındaki korelasyon katsayıları incelenmiştir. Büyüköztürk (2011), değişkenler arasında .80 ve üzerinde ilişkinin bulunmasının çoklu doğrusal bağlantı sorununa yol açabileceğini belirtmiştir. Korelasyon değerleri incelendiğinde çoklu doğrusal bağlantı sorununa yol açabilecek herhangi bir ilişki görülmemiştir. AMOS 24 programında yol analizi yapılmış ve elde edilen uyum iyiliği değerleri incelenmiştir. Model parametrelerini tahmin edebilmek için "maksimum likelihood" seçeneği işaretlenmiştir. 
Modeli değerlendirebilmek amacıyla X²/sd, GFI, CFI, AGFI, NFI, RMSEA ve SRMR değerleri incelenmiştir (Bayram, 2013, s.72-76). Bu değerlerin açıklamaları ve uyum iyiliği aralıkları Tablo 2'de verilmiştir.

\section{BULGULAR}

Otantik liderlik, örgütsel adalet ve iş tatmini değişkenlerine ait ortalamalar, standart sapmalar ve korelasyon değerleri incelenmiştir. Bu değerlere ilişkin veriler Tablo 1'de gösterilmektedir.

Tablo 1. Değişkenlerin ortalamaları, standart sapmaları ve korelasyon değerleri

\begin{tabular}{|c|c|c|c|c|c|}
\hline Değişkenler & Ortalama $(\bar{x})$ & Standart Sapma & 1 & 2 & 3 \\
\hline 1- Otantik Liderlik & 3,78 & ,75 & 1 & & \\
\hline 2- Örgütsel Adalet & 3,86 & ,71 &, $56^{*}$ & 1 & \\
\hline 3- İş Tatmini & 3,42 & ,96 & ,44* & $47^{*}$ & 1 \\
\hline
\end{tabular}
$* \mathrm{p}<.01$

Tablo 1'de görüldüğü üzere, otantik liderlik ile örgütsel adalet arasında pozitif yönlü “orta" düzeyde ( $r=.56, p<.01)$ ilişki bulunmaktadır. Otantik liderlik ile iş tatmini arasında pozitif yönlü "orta" düzeyde $(r=.44, p<.01)$ ilişki olduğu söylenebilir. Örgütsel adalet ile iş tatmini arasında ise pozitif yönlü "orta" düzeyde ( $r=.47, p<.01)$ ilişki olduğu görülmektedir.

Hipotezleri test etmek amacıyla oluşturulan modele ilişkin analiz sonuçları Şekil 2'de gösterilmektedir.

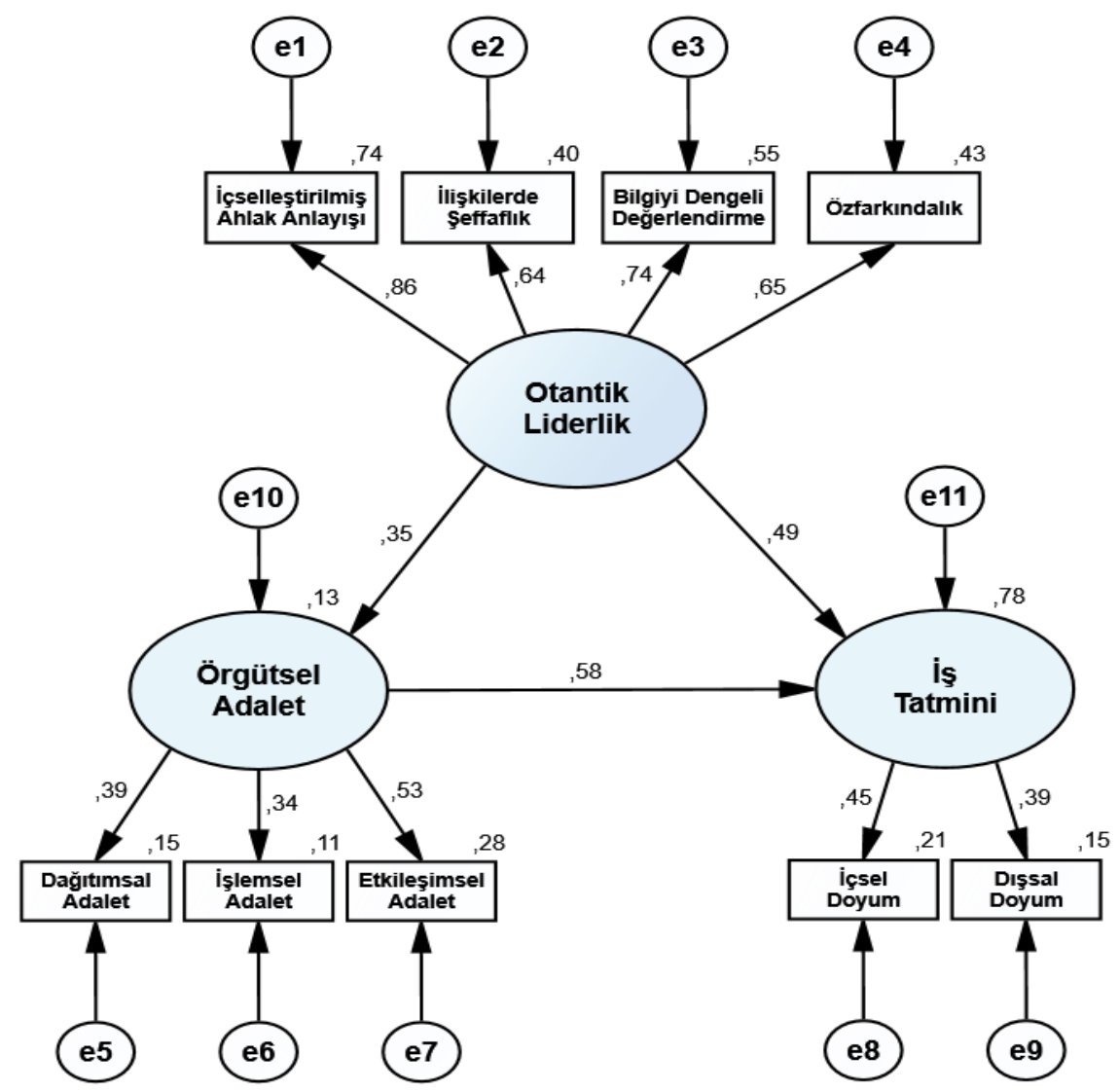

Şekil 2. Araştırmanın Hipotezlerine ilişkin Analiz Sonuçları

Hipotezleri test etmek için oluşturulan modelin uyum iyiliği değerleri Tablo 2'de gösterilmektedir.

Tablo 2. Model uyum indeksleri

\begin{tabular}{lccc}
\hline Uyum İndeksleri & Indeks Kısaltmaları & $\begin{array}{c}\text { Kabul Edilebilir Uyum } \\
\text { Değerleri }\end{array}$ & Model Uyum Değerleri \\
Ki-Kare / Serbestlik Derecesi & $\mathrm{X}^{2} / \mathrm{sd}$ & $0 \leq \mathrm{X}^{2} / \mathrm{sd} \leq 3$ & 1.81 \\
Uyum İyiliği İndeksi & $\mathrm{GFI}$ & $0.90 \leq \mathrm{GFI} \leq 1.00$ & 0.97 \\
Karşılaştırmalı Uyum İndeksi & $\mathrm{CFI}$ & $0.90 \leq \mathrm{CFI} \leq 1.00$ & 0.96 \\
Düzeltilmiş Uyum iyiliği indeksi & $\mathrm{AGFI}$ & $0.85 \leq \mathrm{AGFI} \leq 1.00$ & 0.94 \\
Normlandırılmış Uyum İyiliği İndeksi & $\mathrm{NFI}$ & $0.90 \leq \mathrm{NFI} \leq 1.00$ & 0.91 \\
Yaklaşık Hataların Ortalama Karekökü & $\mathrm{RMSEA}$ & $0.00 \leq \mathrm{RMSEA} \leq 0.8$ & 0.05 \\
Standardize Edilmiş Kalıntıların Ortalama Karekökü & $\mathrm{SRMR}$ & $0.00 \leq \mathrm{SRMR} \leq 0.10$ & 0.04 \\
\hline
\end{tabular}


Tablo 2 incelendiğinde model uyum değerlerinin; $\mathrm{X}^{2} / \mathrm{sd}=1.81, \mathrm{GFI}=0.97, \mathrm{CFI}=0.96, \mathrm{AGFI}=0.94, \mathrm{NFI}=0.91, \mathrm{RMSEA}=0.05$ ve SRMR=0.04 olduğu görülmektedir. Bu sonuçlar modelin uyum iyiliği değerlerinin iyi düzeyde olduğunun göstergesidir (Baumgartner ve Homburg, 1996; Bayram, 2013; Kline, 2016).

Şekil 2'de görüldüğü üzere, otantik liderlik ölçeğinde dört ana gizil değişken olduğu görülmektedir. Otantik liderlik ölçeğinde "içselleştirilmiş ahlak anlayışı" gizil değişkeni .86, "ilişkilerde şeffaflık" gizil değişkeni .64, "bilgiyi dengeli değerlendirme" gizil değişkeni .74 ve "özfarkındalık" gizil değişkeni .65 düzeyinde faktör yüküne sahiptir.

Örgütsel adalet ölçeğinde, üç ana gizil değişken olduğu görülmektedir. Örgütsel adalet ölçeğinde "dağıtımsal adalet" gizil değişkeni .39, "işlemsel adalet" gizil değişkeni .34, "etkileşimsel adalet" gizil değişkeni ise .53 düzeyinde faktör yüküne sahiptir.

İş tatmini ölçeğinde ise iki ana gizil değişken olduğu görülmektedir. İş tatmini ölçeğinde "içsel doyum” gizil değişkeni .45 ve "dışsal doyum" gizil değişkeni ise .39 düzeyinde faktör yüküne sahiptir.

Şekil 2 incelendiğinde otantik liderliğin örgütsel adaleti "orta” etki düzeyinde, pozitif yönde ve anlamlı olarak etkilediği görülmektedir ( $\beta=.35, p<.01, t=3.133$ ). Bu sonuca göre $\mathrm{H} 1$ 'de yer alan "okul yöneticilerinin sergiledikleri otantik liderlik davranışları, örgütsel adaleti pozitif yönde ve anlamlı olarak etkilemektedir" hipotezi doğrulanmaktadır. Ayrıca elde edilen diğer bir sonuca göre otantik liderlik örgütsel adaleti \%13 oranında açıklamaktadır. Yani okullardaki örgütsel adaletin \%13’ünün, otantik liderliğe bağlı olduğu söylenebilir.

Araştırmada, otantik liderliğin iş tatminini "orta" etki düzeyinde, pozitif yönde ve anlamlı olarak etkilediği sonucuna varılmıştır $(\beta=.49, p<.01, t=3.035)$. Bu sonuca göre $H 2$ 'de ifade edilen "okul yöneticilerinin sergiledikleri otantik liderlik davranışları, öğretmenlerin iş tatminini pozitif yönde ve anlamlı olarak etkilemektedir" hipotezi doğrulanmaktadır.

Diğer bir bulguya göre ise okullardaki örgütsel adaletin, iş tatminini "orta" etki düzeyinde pozitif ve anlamlı olarak etkilediği sonucuna varılmıştır $(\beta=.58, p<.01, t=2.281)$. Bu sonuç $\mathrm{H} 3^{\prime}$ de ifade edilen “örgütsel adalet, öğretmenlerin iş tatminini pozitif yönde ve anlamlı olarak etkilemektedir" hipotezini desteklemektedir. Ayrıca elde edilen diğer bir sonuca göre yöneticilerin sergiledikleri otantik liderlik davranışları ile örgütsel adalet birlikte iş tatminini \%78 oranında açıklamaktadır. Yani öğretmenlerin iş tatmininde meydana gelen değişikliklerin \%78'inin, otantik liderlik ve örgütsel adalete bağlı olduğu ifade edilebilir.

\section{SONUÇ, TARTIŞMA VE ÖNERILER}

Çalışmada okul yöneticilerinin sergilediği otantik liderlik davranışlarının, örgütsel adalet ve öğretmenlerin iş tatmini üzerindeki etkisi incelenmiştir. Çalışmanın birinci kısmında literatür taraması yapılarak ilgili kavramlar ve birbirleri ile ilişkileri incelenmiştir. Ayrıca çalışma için model oluşturularak modele uygun hipotezler verilmiştir. Çalışmanın bu kısmında ise hipotezler sırayla ele alınarak, elde edilen sonuçlar başka çalışmaların sonuçlarıyla karşılaştırılmıştır.

Çalışmanın birinci hipotezinden elde edilen bulguya göre, okul yöneticilerinin sergilediği otantik liderlik davranışlarının, örgütsel adaleti pozitif yönde ve anlamlı olarak etkilediği sonucuna varılmıştır. Literatür incelendiğinde bu bulgunun konu ile ilgili yapılan diğer çalışmalar tarafından desteklendiği görülmektedir. Kiersch (2012) otantik liderliğin örgütsel adaletin tüm alt boyutlarını pozitif yönde ve anlamlı olarak etkilediği bulgusuna ulaşmıştır. García-Guiu, Molero ve Moriano (2015), yaptıkları çalışmada otantik liderliğin farklı değişkenler üzerindeki etkilerini incelemiş ve otantik liderliğin örgütsel adaleti pozitif yönde ve anlamlı olarak etkilediği sonucuna ulaşmıştır. Alinezhad, Abbasian ve Behrangi (2015) tarafından okullar evreninde yapılan çalışmada, otantik liderliğin örgütsel adaleti pozitif yönde ve anlamlı olarak etkilediği ifade edilmektedir. Otantik liderliğin, adalet ve adalet iklimi üzerindeki etkilerini ortaya çıkarmak amacıyla yapılan çalışmada Kiersch ve Byrne (2015), otantik liderlik davranışlarının adalet ve adalet iklimi üzerinde olumlu etkilerinin olduğu sonucuna varmıştır.

Çalışmanın ikinci hipotezinden elde edilen bulguya göre, okul yöneticilerinin sergilediği otantik liderlik davranışlarının, öğretmenlerin iş tatminini pozitif yönde ve anlamlı olarak etkilediği sonucuna varılmıştır. Bu sonuç, konu ile ilgili yapılan diğer çalışma sonuçlarını desteklemektedir. Ayça (2016) çalışmasında, iş tatmininin alt boyutları olan içsel ve dışsal tatmin ile otantik liderlik arasında yüksek düzeyde ve pozitif yönde anlamlı ilişkinin olduğunu ifade etmiştir. Pür (2019) tarafından yapılan çalışmada ise otantik liderliğin iş tatminini olumlu yönde etkilediği sonucuna varılmıştır. Darvish ve Rezaie (2011) tarafından yapılan çalışmada, otantik liderlik ve iş tatmini arasında anlamlı ve pozitif bir ilişki olduğu ve liderlerin daha otantik olmasının çalışanların iş tatminini artırdığı sonucuna varılmıştır. Choi ve Ahn (2016) yaptıkları çalışmada otantik liderliğin yetkilendirme yoluyla çalışanların örgütsel bağlılıkları ve iş tatmini üzerinde önemli etkileri olduğu sonucuna varmıştır. Uslu (2017) yaptığı çalışmada otantik liderlik algısı ile iş tatmini arasında pozitif yönde anlamlı ilişkinin olduğunu ifade etmiştir. Wong ve Laschinger (2013) yaptıkları çalışmada otantik liderlik, performans, iş tatmini ve yapısal güçlendirme arasındaki ilişkileri incelemiştir. Araştırma soncunda otantik liderliğin yapısal güçlendirmeyi pozitif yönde ve anlamlı olarak etkilediği ve yapısal güçlendirmenin iş tatminini pozitif yönde ve anlamlı olarak etkilediği belirtilmektedir. Ayrıca otantik liderliğin doğrudan iş tatminini pozitif ve anlamlı olarak etkilediği bulgusunada ulaşılmıştır. Başka bir çalışmada Read ve Laschinger (2015) otantik liderliğin iş tatmini üzerinde olumlu etkiye sahip olduğunu ve otantik liderlerin iş tatmini sağladığını belirtmiştir. Yine benzer bir şekilde Laschinger ve Fida (2015) yaptıkları çalışmada, otantik liderlerin iş tatmini sağlayan güçlü profesyonel uygulama ortamları yaratmada önemli bir rol oynadığı sonucuna varmıştır. Eğitim örgütleri evreninde yapılan çalışmada Sinclair (2010), ortaöğretim okulu müdürlerinin otantik liderlik davranışları göstermesinin, öğretmenlerin iş tatminini artırmada önemli bir etken olduğunu ifade etmektedir. Okullar üzerinde yapılan bir başka çalışmada Ding (1992), yüksekokul müdürlerinin otantik liderlik özellikleri ile öğretmenlerin iş tatminleri arasında pozitif yönlü anlamlı ilişkinin olduğunu ifade etmiştir. Tharpe (2017), ilköğretim okul müdürlerinin sergilediği otantik liderlik

| Kastamonu Eğitim Dergisi, 2020, Vol. 28, No. 6| 
davranışlarının, öğretmenlerin iş tatminine önemli katkılarının olduğunu belirtmiştir. Ayrıca konu ile ilgili yapılan diğer çalışmalarda da otantik liderliğin iş tatminini olumlu yönde etkilediği sonucuna ulaşılmıştır (Amunkete ve Rothmann, 2015; Khan ve diğerleri, 2017; Olaniyan ve Hystad, 2016; Onorato ve Zhu, 2015; Penger ve Černe, 2014; Sultana, Darun ve Yao, 2018).

Çalışmanın üçüncü hipotezinden elde edilen bulguya göre örgütsel adaletin, öğretmenlerin iş tatminini pozitif yönde ve anlamlı olarak etkilediği sonucuna varılmıştır. Bu sonuç, konu ile ilgili yapılan diğer çalışma sonuçları ile paralellik göstermektedir. Okul öncesinde çalışan öğretmenlerin örgütsel adalet ve iş tatmin düzeylerinin incelendiği araştırmada Tanrıverdi ve Paşaoğlu (2014), örgütsel adaletin öğretmenlerin iş tatmin düzeylerini olumlu bir şekilde etkilediğini ifade etmektedir. Öğretmenler örnekleminde yapılan diğer bir çalışmada Altınkurt ve Yılmaz (2012), okullardaki örgütsel adaletin iş doyumunu anlamlı ve pozitif yönde etkilediği sonucuna varmıştır. Çetin, Basım ve Karataş (2011) tarafından yapılan çalışmada örgütsel adaletin alt boyutları olan işlemsel, etkileşimsel ve dağıtımsal adaletinin artmasıyla, çalışanların işlerine yönelik içsel ve dışşal tatminlerinde artış meydana geldiği ifade edilmektedir. Şeşen (2011) tarafından öğretmenler üzerinde yapılan çalışmada, örgütsel adaletin alt boyutlarının, iş tatminini anlamlı olarak etkilediği belirtilmektedir. Altaş ve Çekmecelioğlu (2015), katılımcılarını okul öncesi öğretmenlerin oluşturduğu çalışmada, örgütsel adaletin iş tatmini üzerinde pozitif etkilere sahip olduğunu ifade etmektedir. Çelik ve Gürsel (2017) tarafından yapılan çalışmada, öğretmenlerin algıladı̆̆ı örgütsel adalet algılarının, iş doyumlarını anlamlı bir şekilde yordadığı belirtilmektedir. Öğretmenler örnekleminde yapılan diğer bir çalışmada Zainalipour, Fini ve Mirkamali (2010), örgütsel adalet ile iş tatmini arasında olumlu yönde ilişkilerin olduğunu ifade etmektedir. Benzer bir şekilde Nojani ve diğerleri (2012) yaptıkları çalışmada, çalışan öğretmenlerin örgütsel adalet algıları ve iş tatminleri arasında anlamlı ilişkilerin olduğunu ifade etmektedir. Diğer bir çalışmada Fatimah, Amiraa ve Halim (2011), örgütsel adalet ve iş tatmini arasında anlamlı ilişkiler olduğunu ve örgütsel adaletin iş tatminini pozitif yönde ve anlamlı olarak etkilediğini belirtmektedir. Altahayneh, Khasawneh ve Abedalhafiz (2014) tarafından yapılan çalışmada, örgütsel adaletin tüm boyutları ile öğretmenlerin iş tatmini arasında pozitif ve anlamlı bir ilişki olduğu belirtilmektedir. Ayrıca konu ile ilgili yapılan diğer çalışmalarda da örgütsel adaletin iş tatminini olumlu yönde etkilediği sonucuna ulaşılmıştır (AlZu'bi, 2010; Chen McCain, Tsai ve Bellino, 2010; Çakar ve Yıldız, 2009; Demir, 2016; Fatt, Khin ve Heng, 2010; Imran, Majeed ve Ayub, 2015; Malik ve Naeem, 2011; Yeşil ve Dereli, 2012).

Çalışma bulgularından birisi okul yöneticilerinin sergilediği otantik liderlik davranışlarının, örgütsel adaleti pozitif yönde ve anlamlı olarak etkilediğidir. Otantik liderler içselleştirilmiş bir ahlak anlayışı benimsediğinden dolayı örgütsel adalet algısının oluşumuna katkıda bulunabilir. Bu bakımdan okul müdürleri otantik liderlik davranışlarının örgütsel adalet oluşumunda katkı sağlayacağı konusunda bilgilendirilmelidir. Bu konuda okul yöneticileri için otantik liderlik davranışlarının tam olarak anlaşılabilmesi bakımından hizmet içi eğitimler düzenlenmelidir. Ayrıca yöneticileri otantik liderlik davranışlarını sergilemeleri bakımından teşvik etmek için örgütsel adaletin okul için sağlayabileceği katkılar hakkında bilgilendirmelerde bulunulmalıdır.

Okul yöneticilerinin sergilediği otantik liderlik davranışlarının, öğretmenlerin iş tatminini pozitif yönde ve anlamlı olarak etkilediği elde edilen diğer bir bulgudur. Çalışanların iş tatmininin sağlanması, örgütün amaçlarına ulaşması ve verimliliğin artması adına önemli bir etkendir. Okul yöneticisinin temel amacı, belirlenen hedeflere ulaşılması olduğu düşünüldüğünde, otantik liderlik davranışlarıyla iş tatmini sağlamalıdır. Okul yöneticilerinin otantik liderlik davranışları konusunda kendisini geliştirmesi için teşvik edilmelidir. MEB tarafından otantik liderlik ve etkileri konsunda eğitimler verilmeli ve yöneticilerin gelişimleri sürekli olarak takip altında tutulmalıdır.

Çalışmada elde edilen diğer bir bulgu ise örgütsel adaletin, öğretmenlerin iş tatminini pozitif yönde ve anlamlı olarak etkilediğidir. Okul yöneticisi, okullarda öğretmenler üzerinde adalet algısı oluşturup iş tatmini sağlayabilir. Okulun belirlediği hedeflerin etkili bir şekilde gerçekleştirilebilmesi için okul yöneticisi, eğitimin uygulayıcısı olan öğretmenlerin desteğini almalıdır. Öğretmenlerin adaletli olarak algıladığı bir ortamda çalışması ve iş tatminlerinin sağlanması onları güdüleyecek ve okulun başarısı için elinden geleni yapmalarını sağlayacaktır. Bu bağlamda okul yöneticisi, örgütsel adaletin hâkim olduğu bir ortamın öğretmenler üzerindeki etkilerini bilerek hareket etmelidir. Dolayısıyla bütün okul yöneticileri, örgütsel adalet algısının iş tatminini artırdığı konusunda bilgilendirilmelidir. Bu konuda seminerler veya hizmet içi eğitimler düzenlenerek okul yöneticilerine gerekli bilgiler verilmelidir. Ayrıca okullardaki örgütsel adalet algılarının belirlenebilmesi için müfettişler görevlendirilmeli ve örgütsel adalet algısının düşük olduğu okullar tespit edilip gerekli düzenlemeler yapılmalıdır.

Araştırmacılar için otantik liderlik davranışlarının, örgütsel adalet ve iş tatmini üzerindeki etkilerinin ayrıntılı ve bir bütün olarak belirlenmesi amacıyla bu çalışmayı nitel olarak gerçekleştirmeleri önerilebilir. Okullarda iş tatmini sağlayabilecek ve örgütsel adelet iklimi oluşturabilecek farklı etkenler üzerinde çalışılabilir. Yöneticilerin sergiledikleri otantik liderlik davranışlarının farklı bağımlı değişkenler üzerindeki etkileri incelenebilir.

\section{KAYNAKÇA}

Adams, J. S. (1965). Injustice in social exchange. L. Berkowitz (Ed.), Advances in experimental social psychology (s. 267-299) içinde. New York: Academic Press.

Akyüz, M. Y. (2002). Çağdaş okulda etkili liderlik. Ege Ĕ̌itim Dergisi, 2(1), 109-119.

Alinezhad, M., Abbasian, H., \& Behrangi, M. R. (2015). Investigating the effects of authentic leadership of managers on organizational commitment of teachers with organizational justice as the mediator variable. Ciência e Natura, 37(6-1), 407-416.

Altahayneh, Z. L., Khasawneh, A., \& Abedalhafiz, A. (2014). Relationship between organizational justice and job satisfaction as perceived by Jordanian physical education teachers. Asian Social Science, 10(4), 131-138. doi:10.5539/ass.v10n4p131 
Altaş, S. S., \& Çekmecelioğlu, H. G. (2015). Örgütsel adalet algısının iş tatmini, örgütsel bağlılık ve iş performansı üzerindeki etkileri: okul öncesi öğretmenleri üzerinde bir araştırma. Atatürk Üniversitesi İktisadi ve İdari Bilimler Dergisi, 29(3), 421-439. doi: 10.16951/iibd.01902

Al-Zu'bi, H. A. (2010). A study of relationship between organizational justice and job satisfaction. International Journal of Business and Management, 5(12), 102-109

Amunkete, S., \& Rothmann, S. (2015). Authentic leadership, psychological capital, job satisfaction and intention to leave in state-owned enterprises. Journal of Psychology in Africa, 25(4), 271-281. doi: 10.1080/14330237.2015.1078082

Arifin, H. M. (2015). The influence of competence, motivation and organisational culture to high school teacher job satisfaction and performance. International Education Studies, 8(1), 38-45.

Altınkurt, Y., \& Yılmaz, K. (2012). Ortaöğretim okullarında değerlerle yönetim, örgütsel adalet ve iş doyumu arasındaki ilişki. Sakarya Üniversitesi Ĕ̈itim Fakültesi Dergisi, 2(4), 50-68.

Avolio, B. J., \& Gardner, W. L. (2005). Authentic leadership development: Getting to the root of positive forms of leadership. The Leadership Quarterly, 16(3), 315-338. doi: 10.1016/j.leaqua.2005.03.001

Ayça, B. (2016). Otantik liderlik davranışının iş tatmini ve örgütsel bağlılı̆̆a etkisinin incelenmesi: Otel işletmelerinde bir araştırma (Yayınlanmamış Doktora Tezi). Haliç Üniversitesi Sosyal Bilimler Enstitüsü, İstanbul.

Bakan, İ., \& Büyükbeşe, T. (2004). Örgütsel iletişim ile iş tatmini unsurları arasındaki ilişkiler: akademik örgütler için bir alan araştırması. Akdeniz Üniversitesi İktisadi ve İdari Bilimler Fakültesi Dergisi, (7), 1-30.

Barlı, Ö. (2008). Davranış bilimleri ve örgütlerde davranış (3. Baskı). Ankara: Aktif Yayınevi.

Baş, T., \& Ardıç, K. (2002). Yükseköğretimde iş tatmini ve tatminsizlik. İktisat İşletme ve Finans, 17(198), 72-81.

Baumgartner, H., \& Homburg, C. (1996). Applications of structural equation modeling in marketing and consumer research: A review. International Journal of Research in Marketing, 13(2), 139-161. doi: 10.1016/0167-8116(95)00038-0

Baycan, F. A. (1985). An analysis of the several aspects of job satisfaction between different occupational groups (Yayımlanmamıs Doktora Tezi). Boğaziçi Üniversitesi Sosyal Bilimler Enstitüsü, İstanbul.

Bayram, N. (2013). Yapısal eşitlik modellemesine giriş. Amos uygulamaları. İstanbul: Ezgi.

Bies, R. J., \& Moag, J. S. (1986). Interactional justice: Communication criteria of fairness. R. J. Lewicki, B. H. Sheppard \& M. H. Bazerman (Ed.), Research on negotiation in organizations (s.43-55) içinde. Greenwich, CT: JAI Press.

Budak A. (2006). Kamu sektöründe çalışanların iş tatmin düzeyi: Milli savunma bakanlığı akaryakıt ikmal ve nato pol tesislerinde bir uygulama (Yayınlanmamış Yüksek Lisans Tezi). Anadolu Üniversitesi, Eskişehir

Büyükgöze, H., \& Özdemir, M. (2017). İş doyumu ile öğretmen performansı ilişkisinin duygusal olaylar kuramı çerçevesinde incelenmesi. İnonu University Journal of the Faculty of Education, 18(1), 311-325. doi: 10.17679/inuefd.307041

Büyüköztürk, Ş. (2011), Sosyal bilimler için veri analizi el kitabı: İstatistik, araşstırma deseni SPSS uygulamaları ve yorum (13. Basım). Ankara: Pegem.

Caza, A., Bagozzi, R. P., Woolley, L., Levy, L., \& Barker Caza, B. (2010). Psychological capital and authentic leadership: Measurement, gender, and cultural extension. Asia-Pacific Journal of Business Administration, 2(1), 53-70.doi: 10.1108/17574321011028972

Chan, A., Hannah, S. T., \& Gardner, W. L. (2005). Veritable authentic leadership: Emergence, functioning, and impacts. W. L. Gardner, B. J. Avolio \& F. O. Walumbwa (Ed.), Authentic leadership theory and practice: Origins, effects and development (s. 3-41) içinde. New York: McGraw-Hill.

Chen McCain, S. L., Tsai, H., \& Bellino, N. (2010). Organizational justice, employees' ethical behavior, and job satisfaction in the casino industry. International Journal of Contemporary Hospitality Management, 22(7), 992-1009. doi: 10.1108/09596111011066644

Chamundeswari, S. (2013). Job satisfaction and performance of school teachers. International Journal of Academic Research in Business and Social Sciences, 3(5), 420-428.

Choi, H. G., \& Ahn, S. H. (2016). Influence of nurse managers' authentic leadership on nurses' organizational commitment and job satisfaction: Focused on the mediating effects of empowerment. Journal of Korean Academy of Nursing, 46(1), 100-108. doi: 10.4040/jkan.2016.46.1.100

Cohen, R. L. (1987). Distributive justice: Theory and research. Social Justice Research, 1(1), 19-40. doi: 10.1007/BF01049382

Colquitt, J. A. (2001). On the dimensionality of organizational justice: A construct validation of a measure. Journal of Applied Psychology, 86(3), 386-400. doi: 10.1037//0021-9010.86.3.386

Çakar, N. D., \& Yildiz, S. (2009). Örgütsel adaletin iş tatmini üzerindeki etkisi: "Algılanan örgütsel destek" bir ara değişken mi? Elektronik Sosyal Bilimler Dergisi, 8(28), 68-90.

Çelik, O. T., \& Gürsel, M. (2017). İlköğretim okulu öğretmenlerinin örgütsel adalet algıları ve iş doyumları arasındaki ilişki. İnönü Üniversitesi Eğitim Bilimleri Enstitüsü Dergisi, 4(7), 47-56. doi: 10.29129/inujgse.347677

Çetin, F., Basım, H. N., \& Karataş, M. (2011). Çalışanların problem çözme becerilerinde örgütsel adalet algısı ve iş tatmininin rolü. Yönetim ve Ekonomi, 18(1), 71-85.

Darvish, H., \& Rezaei, F. (2011). The impact of authentic leadership on job satisfaction and team commitment. Management and Marketing, 6(3), 421-436. 
DeConinck, J. B., \& Stilwell, C. D. (2004). Incorporating organizational justice, role states, pay satisfaction and supervisor satisfaction in a model of turnover intentions. Journal of Business Research, 57(3), 225-231.

Demir, K. (2016). Relations between teachers' organizational justice perceptions and organizational commitment and job satisfaction in the school: A meta-analysis. Journal of Human Sciences, 13(1), 1408-1417.

Ding, W. (1992). Relationships among principals' leadership behavior, principals' authenticity, and teacher job satisfaction in selected junior high schools. (Order No. 9235577, University of Northern Colorado).

Elma, C. (2013). The predictive value of teachers' perception of organizational justice on job satisfaction. Eurasian Journal of Educational Research, 51, 157-176.

Fatimah, O., Amiraa, A. M., \& Halim, F. W. (2011). The relationships between organizational justice, organizational citizenship behavior and job satisfaction. Pertanika Journal of Social Sciences \& Humanities, 19, 115-121.

Fatt, C. K., Khin, E. W. S., \& Heng, T. N. (2010). The impact of organizational justice on employee's job satisfaction: The Malaysian companies perspectives. American Journal of Economics and Business Administration, 2(1), 56-63.

Folger, R., \& Cronpanzano, R. (1998). Organizational justice and human resource management. Thousand Oaks, CA: Sage Publications.

Folger, R., \& Konovsky, M. A. (1989). Effects of procedural and distributive justice on reactions to pay raise decisions. Academy of Management journal, 32(1), 115-130. doi: 10.5465/256422

García-Guiu, C., Molero, F., \& Moriano, J. A. (2015). Authentic leadership and its influence on group cohesion and organizational identification: the role of organizational justice as a mediating variable. Revista de Psicología Social, 30(1), 60-88. doi: 10.1080/02134748.2014.987539

Gardner, W. L., Avolio, B. J., Luthans, F., May, D. R., \& Walumbwa, F. (2005). "Can you see the real me?" A self-based model of authentic leader and follower development. The Leadership Quarterly, 16(3), 343-372. doi: 10.1016/j.leaqua.2005.03.003

George, B. (2003). Authentic leadership: Rediscovering the secrets to creating lasting value. San Francisco, CA: Jossey-Bass.

Greenberg, J. (1996), The quest for justice on the job: Essays and experiments. Thousand Oaks, CA: Sage Publications.

Harvey, P., Martinko, M. J., \& Gardner, W. L. (2006). Promoting authentic behavior in organizations: An attributional perspective. Journal of Leadership \& Organizational Studies, 12(3), 1-11. doi: 10.1177/107179190601200301

Helvacı, M. A., \& Aydoğan, İ. (2011). Etkili okul ve etkili okul müdürüne ilişkin öğretmen görüşleri. Uşak Üniversitesi Sosyal Bilimler Dergisi, 4(2), 41-60.

Ilies, R., Morgeson, F. P., \& Nahrgang, J. D. (2005). Authentic leadership and eudaemonic well-being: Understanding leader-follower outcomes. The Leadership Quarterly, 16(3), 373-394. doi: 10.1016/j.leaqua.2005.03.002

Imran, R., Majeed, M., \& Ayub, A. (2015). Impact of organizational justice, job security and job satisfaction on organizational productivity. Journal of Economics, Business and Management, 3(9), 840-845.

Karasar, N. (2013). Bilimsel araştırma yöntemi (25.Bask1). Ankara: Nobel Yayıncılık.

Karimi, A., Alipour, O., Pour, M. A., \& Azizi, B. (2013). Relationship between organizational justice and job satisfaction in ministry of sports and youth in Iran. International Journal Sport Studies, 3(11), 1149-56.

Kernis, M. H. (2003). Toward a conceptualization of optimal self-esteem. Psychological Inquiry, 14(1),1-26. doi:10.1207/S15327965PLI1401_01

Keser, S., \& Kocabaş, İ. (2014). İlköğretim okulu yöneticilerinin otantik liderlik ve psikolojik sermaye özelliklerinin karşılaştırılması. Kuram ve Uygulamada Ĕ̈itim Yönetimi, 20(1), 1-22. doi: 10.14527/kuey.2014.001

Khan, S., Muhammad, B., Afridi, G. W., \& Sarwar, I. (2017). Effect of authentic leadership on job satisfaction and employee engagement. City University Research Journal, 7(1), 151-166.

Kılıç, M. Y. (2019). Okullarda yöneticinin sağladığı etik iklimin, örgütsel bağl1lık ve öğretmen performansına etkisi. Cumhuriyet International Journal of Education, 8(3), 807-836. doi: 10.30703/cije.561366

Kiersch, C. E. (2012). A multi-level examination of authentic leadership and organizational justice in uncertain times (Yayınlanmamış Doktora Tezi). Colorado State University, Colorado.

Kiersch, C. E., \& Byrne, Z. S. (2015). Is being authentic being fair? Multilevel examination of authentic leadership, justice, and employee outcomes. Journal of Leadership \& Organizational Studies, 22(3), 292-303.

Kim, W. C., \& Mauborgne, R. A. (1993). Procedural justice, attitudes, and subsidiary top management compliance with multinationals' corporate strategic decisions. Academy of Management Journal, 36(3), 502-526. doi: 10.5465/256590

Kim, W. C., \& Mauborgne, R. A. (2005). Blue ocean strategy: How to create uncontested market space and make competition irrelevant. Cambridge, MA: Harvard Business School Press.

Kline, R. B. (2016). Principles and practice of structural equation modeling. New York: The Guilford Press.

Laschinger, H. K. S., \& Fida, R. (2015). Linking nurses' perceptions of patient care quality to job satisfaction: the role of authentic leadership and empowering professional practice environments. Journal of Nursing Administration, 45(5), 276-283. doi: 10.1097/NNA.0000000000000198

Lezotte, L. W. (1992). Creating the total quality effective school. Michigan: Effective Schools Products

Lind, E. A., \& Tyler, T. R. (1988). The social psychology of procedural justice. New York: Plenum Press 
Locke, E. A. (1976). The nature and causes of job satisfaction. M. D. Dunnette (Ed.), Handbook of industrial and organizational psychology (s. 1297-1343) içinde. Chicago, IL: Rand McNally.

Luthans, F. (1995). Organizational behavior. New York: McGraw Hill.

Luthans F., \& Avolio B. J. (2003). Authentic leadership: A positive developmental approach. K.S. Cameron, J. E. Dutton \& R. E. Quinn (Ed.), Positive organizational scholarship (s. 241-261) içinde. San Francisco: Barrett-Koehler.

Malik, M. E., \& Naeem, B. (2011). Role of perceived organizational justice in job satisfaction: Evidence from higher education institutions of Pakistan. Interdisciplinary Journal of Contemporary Research in Business, 3(8), 662-673.

May, D. R., Chan, A. Y., Hodges, T. D., \& Avolio, B. J. (2003). Developing the moral component of authentic leadership. Organizational Dynamics, 32(3), 247-260. doi: 10.1016/S0090-2616(03)00032-9

Moorman, R. H. (1991). Relationship between organizational justice and organizational citizenship behaviors: Do fairness perceptions influence employee citizenship? Journal of Applied Psychology, 76(6), 845-855. doi: 10.1037/0021-9010.76.6.845.

Niehoff, B. P., \& Moorman, R. H. (1993). Justice as a mediator of the relationship between methods of monitoring and organizational citizenship behavior. Academy of Management Journal, 36(3), 527-556. doi: 10.5465/256591

Nojani, M. I., Arjmandnia, A. A., Afrooz, G. A., \& Rajabi, M. (2012). The study on relationship between organizational justice and job satisfaction in teachers working in general, special and gifted education systems. Procedia-Social and Behavioral Sciences, 46, $2900-2905$.

Olaniyan, O. S., \& Hystad, S. W. (2016). Employees' psychological capital, job satisfaction, insecurity, and intentions to quit: The direct and indirect effects of authentic leadership. Revista de Psicología del Trabajo y de las Organizaciones, 32(3), 163-171. doi: 10.1016/j.rpto.2016.09.003

Onorato, M., \& Zhu, J. (2015). The Relationship between authentic leadership and employee job satisfaction: A cross-industry-sector empirical study. International Leadership Journal, 7(2), 81-103.

Özaydın, M. M., \& Özdemir, Ö. (2014). Çalışanların bireysel özelliklerinin iş tatmini üzerindeki etkileri: Bir kamu bankası örneği. Işsletme Araştırmaları Dergisi, 6(1), 251-281.

Özcan, E. D. (2011). Kişilik bakış açısından örgüt yapısı ve iş tatmini. İstanbul: Beta Basım Yayım.

Penger, S., \& Černe, M. (2014). Authentic leadership, employees' job satisfaction, and work engagement: A hierarchical linear modelling approach. Economic Research-Ekonomska Istraživanja, 27(1), 508-526. doi: 10.1080/1331677X.2014.974340

Pfeffer, J., \& Langton, N. (1993). The effect of wage dispersion on satisfaction, productivity, and working collaboratively: Evidence from college and university faculty. Administrative Science Quarterly, 38(3), 382-407. doi: 10.2307/2393373

Polat, S. (2007). Ortaöğretim ögretmenlerinin örgütsel adalet algıları, örgütsel güven düzeyleri ile örgütsel vatandaşlık davranışları arasındaki ilişki (Yayımlanmamış Doktora Tezi). Kocaeli Üniversitesi Sosyal Bilimler Enstitüsü. Kocaeli.

Pür, F (2019). Psikolojik sermayenin iş tatminine etkisinde otantik liderliğin düzenleyici etkisi üzerine bir araştırma (Yayınlanmamış Yüksek Lisans Tezi). Beykent Üniversitesi Sosyal Bilimler Enstitüsü, İstanbul.

Read, E. A., \& Laschinger, H. K. (2015). The influence of authentic leadership and empowerment on nurses' relational social capital, mental health and job satisfaction over the first year of practice. Journal of Advanced Nursing, 71(7), 1611-1623. doi: 10.1111/jan.12625

Reitzug, U. C. (1989). Principal-teacher interactions in instructionally effective and ordinary elementary schools. Urban Education, 24(1), 38-58. doi: $10.1177 / 0042085989024001003$

Shamir, B., \& Eilam, G. (2005). "What's your story?" A life-stories approach to authentic leadership development. The Leadership Quarterly, 16(3), 395-417. doi: 10.1016/j.leaqua.2005.03.005

Sinclair, M. (2010). Authentic leadership behaviors of secondary school principals and job satisfaction of the multigenerational teacher workforce. University of La Verne.

Sia, L. A., \& Tan, T. A. (2016). The influence of organizational justice on job satisfaction in a hotel setting. DLSU Business \& Economics Review, 26(1), 17-29.

Sultana, U. S., Darun, M. R., \& Yao, L. (2018). Authentic leadership and psychological capital: a mingle effort to increase job satisfaction and lessen job stress. Indian Journal of Science and Technology, 11(5), 1-13.

Şeşen, H. (2011). Adalet algısının tükenmişliğe etkisi: İş tatmininin aracı değişken rolünün yapısal eşitlik modeli ile testi. Savunma Bilimleri Dergisi, 9(2), 67-90.

Tabachnick, B. G., \& Fidell, L. S. (2013).Using multivariate statistics. Boston: Pearson.

Tabak, A., Polat, M., Coşar, S., \& Türköz, T. (2012). Otantik liderlik ölçeği: Güvenirlik ve geçerlik çalışması. İş, Güç: The Journal of Industrial Relations \& Human Resources, 14(4), 89-106. doi: 10.4026/1303 2860.2012.0212.x

Tanrıverdi, H., \& Paşaoğlu, S. (2014). Dönüşümcü liderlik, örgütsel adalet ve iş tatmini arasındaki ilişkileri belirlemeye yönelik okul öncesi öğretmenleri üzerinde bir araştırma. Electronic Journal of Social Sciences, 13(50), 274-293.

Tharpe, P. (2017). Authentic leadership behaviors contributing to job satisfaction of elementary school principals and elementary special education teachers (Yayınlanmamış Doktora Tezi). Brandman University.

Ugboro, I. O., \& Obeng, K. (2000). Top management leadership, employee empowerment, job satisfaction, and customer satisfaction in TQM organizations: an empirical study. Journal of Quality Management, 5(2), 247-272. doi: 10.1016/S1084-8568(01)00023-2 
Uslu (2017). Otantik liderlik ile iş tatmini arasındaki ilişsinin incelenmesi: çalışanların kişilik özelliklerinin düzenleyici etkisi (Yayınlanmamış Yüksek Lisans Tezi). Hacettepe Üniversitesi Sosyal Bilimler Enstitüsü, Ankara.

Walumbwa, F. O., Avolio, B. J., Gardner, W. L., Wernsing, T. S., \& Peterson, S. J. (2008). Authentic leadership: Development and validation of a theory-based measure. Journal of Management, 34(1), 89-126. doi: 10.1177/0149206307308913

Weiss, D. J., Dawis, R. V., England, G. W., \& Lofquist, L. H. (1967). Manual for the minnesota satisfaction questionnaire. Minnesota Studies in Vocational Rehabilitation, 22, 120.

Wong, C. A., \& Laschinger, H. K. (2013). Authentic leadership, performance, and job satisfaction: the mediating role of empowerment. Journal of Advanced Nursing, 69(4), 947-959. doi: 10.1111/j.1365-2648.2012.06089.x

Yavuz, M. (2012). Özel dershanelerde görev yapan öğretmenlerin örgütsel adalet algıları. Turkish Studies-International Periodical For The Languages, 7(2), 1147-1160.

Yazıcıŏglu, İ. (2010). Örgütlerde iş tatmini ve işgören performansı ilişkisi: Türkiye ve Kazakistan karşılaştırması. Bilig, 55(1), $243-264$.

Yeşil, S., \& Dereli, S. F. (2012). Örgütsel adalet ve iş tatmini üzerine bir alan çalışması. Kahramanmaraşs Sütçü İmam Üniversitesi İktisadi ve Idari Bilimler Fakültesi Dergisi, 2(1), 105-122.

Zainalipour, H., Fini, A. A. S., \& Mirkamali, S. M. (2010). A study of relationship between organizational justice and job satisfaction among teachers in Bandar Abbas middle school. Procedia-Social and Behavioral Sciences, 5, 1986-1990. doi: 10.1016/j.sbspro.2010.07.401 